\title{
Myths and Self-Deceptions about the Greek Debt Crisis*
}

\author{
Stergios Skaperdas \\ Department of Economics \\ University of California, Irvine \\ Revised on June 12, 2015
}

\begin{abstract}
The long-running Greek public debt crisis has been accompanied by an information war that has obscured what has occurred. The misconceptions, selfdeceptions, and myths associated with the crisis have been at least partly responsible for the obviously inadequate response to the crisis and for the damage to the economies and societies of primarily Greece but also of other Eurozone countries. I argue against seven such myths about the effects of default, the primary cause of the crisis, the likely effects of an exit from the eurozone, the bargaining power of the Greek government in its negotiations with the EU/ECB/IMF troika, and others. I also discuss the context of the wider slippage of democracy in the European Union and future prospects.
\end{abstract}

Keywords: Eurozone, Greece, debt, default. JEL codes: D70, E50, H50, H60

*This is a significantly revised, updated, and expanded version of Skaperdas (2011b). For discussions and comments I am grateful to Jean-Paul Carvalho, Michelle Garfinkel, Gikas Hardouvelis, Costas Lapavitsas, Paul Lowood, Thomas Moutos, Athanasios Orphanides, Gary Richardson, Nicholas Sambanis, Fanis Tsoulouhas, Mehrdad Vahabi, seminar participants at UC Irvine, UCLA, and the University of Paris VIII, and especially an official who wishes to remain anonymous. None is responsible, and some are critical of, the ideas and arguments presented in this paper. 
In May 2010 and early 2012 Greece went through two different "bailouts" that were supposed to make its debt sustainable and, after a temporary dip, bring its economy back to economic growth. Yet between 2008 and 2014 the Greek economy contracted by more than $25 \%$. The unemployment rate has been higher than $25 \%$ since mid-2012. Despite a reduction in wages approaching $30 \%$ - an "internal devaluation" policy decision explicitly undertaken in order to make the Greek economy more internationally competitive - Greek exports at the end of 2014 were about $10 \%$ lower than they were in 2008 (Maliaropulos, 2015, p.18). This is comparable to the worst economic performances during the Great Depression. No high-income country has had a comparable contraction in the post-war period.

While the debt-to-GDP ratio stood a bit over $120 \%$ at the end of 2009 , it is now close to $180 \%$. Thus, on every count imaginable the "bailouts" have been disastrous for Greece and a problem for the rest of the Eurozone countries. Yet the same recipes are contemplated on the eve of either a new "bailout" or default followed by a probable Greek exit from the Eurozone. Almost nothing appears to have been learned from the experience of the past five years.

This seeming absence of learning, I suggest, is a consequence of a surprising number of widely-held misconceptions, self-deceptions, and myths about the causes, consequences, and available policies to combat the crisis. Some of the misconceptions are consciously propagated by governments and mainstream media while they know that they are untrue. Other misconceptions might be apparently believed by government officials, those close to them, and most of the press. Their persistence, however, despite the five years of failure of the Greek program suggests that it serves the interests of at least a few key constituencies.

Many Greeks and other European citizens who are not economists or experts consciously or instinctively understand that there is a serious problem with the dominant narrative, but they do not have the knowledge to argue in detail against the misconceptions.

Moreover, many of those who know better and could argue against the misconceptions either self-censor or have difficulties in having their views heard through the mainstream $\mathrm{m}$ edia. My sense is that, curiously, there is less debate and fewer challenges to misconceptions within eurozone countries than outside of them. Perhaps this is because outside observers are less constrained in expressing their independent assessment of the problems facing the eurozone and Greece.

I argue against the following eight myths:

- Myth \#1: Default or "bankruptcy" would have been (and still would be) catastrophic for Greece.

- Myth \#2: The troika's objective has been to "rescue" Greece.

- Myth \#3: The main cause of the crisis was the corruption of Greeks and the Greek State

- Myth \#4: If only the Greek governments were competent, the targets of the Memoranda in the agreements would not have failed. 
- Myth \#5: Following the troika's policies would have lead Greece back to prosperity.

- Myth \#6: Exit from the eurozone would have been (and still is) the worst possible outcome for Greece.

- Myth \#7: In its negotiations with the troika, the Greek governments have had very little bargaining power.

I consider each myth in turn and offer relevant facts and history as needed. I then briefly offer some observations about why these myths have persisted. I then discuss how the pattern of decision-making within the Eurozone and the European Union more generally pose a serious challenge to democracy throughout Europe, and how wide swaths of European elites and European intellectuals appear to ignore this fundamental problem. At the end I offer some concluding remarks.

\section{Myth \#1: Default or "bankruptcy" would have been (and still would be) catastrophic for Greece.}

This was probably the myth most repeated within Greece at the beginning of the crisis, from early 2010. The Prime Minister at the time, Mr. Papandreou (from late 2009 to late 2011), as well as other government officials were insistent on propagating the idea that default would have been catastrophic and they continued to do so unchallenged. Even after Greece effectively defaulted in early 2012, under the so-called Private Sector Initiative (PSI) restructuring of its public debt, default is still widely considered a catastrophic alternative.

One source of the confusion could be the usage of the term "bankruptcy" which has a bad connotation in Greek, especially in connection with personal bankruptcy. It brings to mind images of total destitution, perhaps even indentured servitude. For modern capitalism, though, bankruptcy and debt default along with limited liability are key features. ${ }^{1}$ With limited liability for the borrower it is also the lender's responsibility, not just the borrower's, that loans would be repaid. This, in principle, ensures that not too many bad loans are made and the financial crisis that began in the US shows what occurs when lenders become irresponsible in that system. Thus, debt default and bankruptcy for individuals and corporations are critical attributes in the functioning of modern capitalism. If the lender has not been careful in choosing his borrowers, then it is both economically efficient and fair that he loses. From an economic viewpoint it is clear that the possibility of bankruptcy has been a usually source of improvement, renewal, and vitality in the economies that allowed it. ${ }^{2}$ Default, however, has dimensions other than

\footnotetext{
${ }^{1}$ If, as in the old days, the lender could go after all of a borrower's assets and even enserf him or her so as to ensure full repayment, then the lender would have no incentive to provide loans that have a high chance of being repaid and would use lending primarily as a form of acquiring the borrower's assets, including possibly his labor.

${ }^{2}$ For a fascinating long-run historical perspective on debt, debt jubilees, and bankruptcy, see Graeber (2012).
} 
the economic one with which public debt - as opposed to personal or firm debt - is especially associated.

There are at least three differences between default and bankruptcy, on the one hand, by individuals or corporations and, on the other hand, by sovereign states. First, states do not literally go bankrupt, in the sense that there is no higher supranational ultimate authority and courts that will decide and enforce how the country's assets will be allocated between the different creditors and what will remain with the country's state. Instead, bonds and loans are issued according to the laws of specific jurisdictions, but the ultimate enforcement can be difficult since states are sovereign. As can be expected though when big interests are involved, posturing, bargaining, and even gunboat diplomacy can play a role on what occurs in the event of default. Legally, the vast majority of Greek debt issued before 2010 was governed by Greek law. After the PSI restructuring of 2012, Greek debt came under English and defaulting on that debt would be considerably more difficult than that issued under Greek law, although significant issues of enforceability would still be present.

The second important difference of sovereign debt from other debts is that it is issued and controlled by government officials on behalf of the country and its people. There can be a big difference, however, between the interests of government officials and the interests of the country and its people. One extreme case of such a difference in interests is that of former President Mobutu of Zaire whose international loans were mostly diverted to foreign private bank accounts with the country seeing no benefits and stuck with paying back the loans. But even nominally elected government officials can be parties to loans that are illegal or odious and, thus, there might be a legal or moral basis for negating such debts. Given the numerous scandals that have rocked the previous governing political parties, all previously issued Greek debt needs to be scrutinized for possible illegality and odiousness. For example, the contracts with the investment banks that underwrote bond issues, and the records of their implementation need to be opened as a matter of basic transparency and democratic accountability. That is actually occurring under the new SYRIZA-ANEL government that emerged out of the January 2015 elections.

The third difference is that sovereign debt rarely, if ever, involves explicit collateral. course, one recent exception is Finland's demand for, and receipt of, collateral from Greece in order to participate in the EFSF mechanism in 2012.) Despite this usual absence of collateral, however, it is has historically been difficult to completely dispose of foreign public debt. There is a curious moral dimension to national debt, even though the vast majority of citizens of a country do not have the choice of being citizens, as opposed to the shareholders of corporations who choose to be shareholders yet they have limited liability and no obligations to pay off debts in the event of a default.

Given that default is routine even in cases of individual or corporate debt and the fact that most of Greece's debt was governed by Greek law up to 2012, on balance it would it appear that default would not have been difficult. Why, then, wouldn't the country default on it immediately? 
One reason might be because the country would not have been able to access international capital markets again. Greece, though, has not had access to international markets since early 2010 and there was no clear path going back to those markets. On the contrary, a generous "haircut" would have made the remaining debt sustainable and then foreign creditors who would have been more likely to lend to the country, just as they have done for other countries that have defaulted like Russia and Iceland. How fast Greece could have come back to international bond markets would have depended on the size of the haircut (the higher the haircut, the more sustainable debt becomes) but also on how fast the legal tangles with creditors lasted, with longer outstanding legal issues making return more difficult.

Moreover, there are ways to borrow internationally other than through the bond markets, from other sovereign states or from individual financial institutions. Finally, let us also not forget that before Greece entered the eurozone it borrowed very little from abroad even though its debt-to-GDP ratio was high, and that ratio was sustainable precisely because it was internally held and in its own currency.

If Greece had defaulted in early 2010 Greek debt could have become sustainable in the long run with a writeoffs imposed on bondholders of considerably below $50 \%$ of total debt. The country would have had to borrow internally, perhaps issue IOUs (as it has done already), and impose a few modest cuts. The effect of such a policy would have been mildly recessionary.

What was done in 2010 instead by the troika was to provide Greece with loans so as to cover its budget deficit without default, in exchange for increasingly draconian budget cuts, tax increases, and institutional changes of dubious value. The effect of this policy was a fast downward spiral of the economy. Since debt kept increasing and the country kept getting poorer fast, debt was becoming ever less sustainable. Thus, the second bailout in 2012 restructured Greek debt, with the main losers being Greek pension funds and Greek banks. The Greek state had to borrow 50 billion euros just to recapitalize the banking system and continues to have to cover the losses of the pension funds (in addition to cutting pensions, cutting health expenditures, and increasing retirement ages). The continued contraction of the economy, deflation, and a few additional loans from official sources have brought the debt-to-GDP ratio close to $180 \%$, the highest it has ever been.

Now, default would be considerably more difficult both because Greek public debt is under English law and because 80 percent of it is official and owed to official sources (the IMF, the ECB, and other Eurozone member countries). Yet, that debt is unsustainable and there is virtually no chance it will be fully paid back. Default is still a taboo but it is bound to occur in one way or another, regardless of how it is named.

The decisions by the previous governments that were involved in the 2010 and 2012 agreements doomed the country to a depression and tied the hands of the country and future governments. The myth of "default equals catastrophe" was a significant political contributor in not seeking a default in 2010 and having a default that has been obviously 
creditor-friendly in 2012. A similar mentality appears to characterize many members of the current Greek government as well, thus making it probable that a "kick-the-candown-the-road" strategy will be followed. Such a policy, because it would necessitate additional budget cuts and taxes, would prolong the Depression with obvious economic and social consequences but difficult to predict political and geopolitical consequences.

\section{Myth \#2: The troika's objective was to "rescue" Greece.}

"[The May 2010 agreement] was about protecting German banks, but especially the French banks, from debt write offs."

Karl Otto Pöhl (former head of the German Central Bank) Spiegel, May 18, 2010

Any casual reader of the international, European, and Greek presses over the past five years would consider axiomatic and beyond doubt that the main objective of troika policies has been the "rescue" and "saving" of Greece. This comes along with the narrative that all Greeks have been profligate "sinners" and the troika has been a benevolent dictator who has not only rescuing them materially now but has also been forcing them to transform their institutions in ways that will bring them long-term prosperity.

Let us first review who has gained and who has lost from the "rescue" thus far. Here, at the beginning of 2010 the two immediate parties with large stakes were on one side the vast majority of Greeks and on the other side the country's creditors. The 2010 agreement, as former Bundesbank President Karl Otto Pöhl has confessed, essentially bailed out the private creditors. That agreement did not involve any debt write-offs and instead largely transferred the risk to official creditors. The view was similar even within the IMF. A leaked confidential IMF report from the time mentions:

The exceptionally high risks of the program were recognized by staff itself, in particular in its assessment of debt sustainability... ...

Several chairs (Argentina, Brazil, India, Russia, and Switzerland) lamented that the program has a missing element: it should have included debt restructuring and Private Sector Involvement (PSI), to avoid, according to the Brazilian ED, " $a$ bailout of Greece's private sector bondholders, mainly European financial institutions" (IMF, 2010, emphasis in the original)

Thus, even official, albeit confidential, documents of the IMF feature the bailout of private creditors in the 2010 agreement. Moreover, the report highlights the problem of debt sustainability, ${ }^{3}$ something that became increasingly evident during 2011 and culminated in the agreement of 2012 that did involve PSI. (See also the recounting of these events by Blustein, 2015.)

\footnotetext{
${ }^{3}$ It should be mentioned that the issues raised in this confidential document raised both legal and moral questions about both the 2010 and 2012 agreements. For example, they could be used in support of declaring part of Greece's public debt as "odious."
} 
However, by that time private bondholders were international financial institutions that had obtained the bonds at a significant discount (in the expectation of default), Greek pension funds that had to keep their assets in Greek government bonds, or Greek banks that had limited choices. Greek bonds held by the European Central Bank were exempted from the PSI. Thus, most of the costs of the write-offs of the PSI were absorbed by Greek entities and the Greek state had to borrow to recapitalize the banks (still privately held) or to bear the cost of the losses by the pension funds. Furthermore, the remaining Eurozone countries took on the risk of a debt burden that is clearly unsustainable.

The two agreements necessitated increasingly brutal budget cuts whose effects migrated fast from the public sector and the banks to the private real economy where credit was choked off, especially given the idiosyncratic financing through post-dated checks and other institutional adaptations of the vital small business sector. As the predictable depression deepened, the demands of ever greater budget cuts, unrealistic privatization plans, and wholesale cookie-cutter institutional changes that show no concern for the Greek Constitution or Greek laws and have no hope of working are still peddled to this day as a "rescue" of Greece.

\section{Alternatives to the troika's "rescue"}

Defenders of the two agreements typically say that the alternative would have been "bankruptcy" which, of course, according to myth \#1 would have been catastrophic. So let us consider the alternative of "bankruptcy" in early 2010. The debt-to-GDP ratio was less than 120 percent at the time. A write-off of 30 percent would have made the debt sustainable in the long run, but certainly that is below the levels that would make Greek debt sustainable now.

Defenders of the response to the Greek debt crisis could then retort that, after a default in early 2010, Greece (i) would be shut out from the international bond markets and (ii) because it did not have a primary budget surplus (the government budget surplus excluding interest on debt), the government would have been unable to pay wages, pensions and its other bills.

While in the short run international bond markets would not have lent to Greece immediately, the bigger the write-off the more easily and faster would Greece have come back to these markets. But these would not have been needed and, in any case, it is probably unwise for Greece to go have gone back to them any time soon. Even if foreign lending from sources other than bond markets were not to become available, ordinary Greeks would have gladly bought Greek government bonds at $4.5 \%$ instead of the $2 \%$ or lower they had been getting in their bank accounts. ${ }^{4}$

\footnotetext{
${ }^{4}$ Initially, this domestic purchase of bonds would have come from existing assets, primarily bank deposits. To continue this practice for additional years a significant increase in Greece's savings rate would have to take place. The buying of government bonds would have reduced deposits with Greek banks that would have, it turn, induced a combination of deleveraging and financing from the ECB or through the Bank of
} 
Furthermore, cuts across the board could have taken place but instead of cuts probably more effective would have been part payment in IOUs or bills that could be negotiable, at a discount, and play the role of near-money. Such a move would have also enhanced liquidity in the private sector and prevented the ongoing depression that the troika's policies have induced. Again, a condition for all of these to have occurred is a deep enough writeoff, a dreaded "bankruptcy," that would have reduced public debt to sustainable levels in the eyes of everybody, including Greeks.

The welfare of ordinary Greeks - that their "rescue" would be expected to take account of - does not appear to have figured out at all in the calculations of the troika, not even through its negative feedback effects on the realization of the troika's assumed objectives and the threat a default of Greece poses for the international financial system. The policies pursued were consistent with the short-run interests of banks from the eurozone center and perhaps with some other private interests; they did not appear to take adequate account of the contagion and other risks the policies posed to the eurozone and the rest of the world; and certainly ordinary Greeks were not considered except possibly as "sinners" who need to be punished

The myth of the "rescue" of Greece, however, has persisted. Moreover, it has had powerful real, negative effects on the politics and economics of the crisis not just in Greece but throughout the eurozone.

First, the framing of a "rescue" has allowed the German and other European elites to divert attention away from the "bailout" of the banking sector and bondholders, although it certainly has not worked to their satisfaction.

Second, it has fuelled populist rage in Northern Europe against the "lazy" common Greeks, precisely those who benefited the least from Greek public debt and who have solely paid and are expected to pay the costs of the crisis thus far. It has also diverted attention from the causes of wage stagnation in Germany, which, by the way, is an important factor in increasing Germany's current account surpluses and contributed to the imbalances within the eurozone.

Finally, by internalizing and propagating the myth of "rescue," the Greek governments themselves have helped prevent any genuine debate on alternatives within.

\section{Myth \#3: The main cause of the crisis is the corruption of Greeks and the Greek State}

"The painful adjustment policies now taking place in a number of eurozone countries are a direct result of their adoption of the euro." (Feldstein, 2011, p.5)

Greece using the ELA (Emergency Liquidity Assistance) mechanism. The reduction of bank deposits has taken place anyway without this early default scenario. 
It is one thing to argue that there is corruption in Greece and altogether a different matter to blame it as the primary the cause of the crisis.

\section{The public sector and corruption}

There have of course been many problems with the Greek state and the way the Greek clientelistic political system has been operating. ${ }^{5}$ But similar problems with the state exist in Italy, Spain and elsewhere. And one can have frustrating experiences with the "bureaucracy" in Germany too - by its nature, a big part of the rule of law and democracy does require extensive rules and bureaucratic organization that may seem less efficient to market exchange, but which are necessary and productive overall. Nobody, of course, likes corruption but there is very little known about how to combat it and it should not be confused with the size of the government sector, as the richer the country is the higher tends to be its government sector as a percentage of its GDP.

Figure 1 depicts the total number of public workers as a percent of the labor force in OECD countries for 2000 and 2008. General government workers are in blue whereas the purple bands include the employees of public corporations (like the railroad and electricity companies). Greece has few general government workers - fewer than any European OECD country in the sample -- but more employees in public corporations than in general government, as well as a higher percentage of public corporation employees than any other country. Still the total percentage of public employees was considerably lower than those of countries like Finland, Slovenia and Estonia and comparable to those of Hungary, Slovakia and the Czech Republic.

Since in other countries many of the services performed by public corporations in Greece are privatized, it is not possible to conclude from this information alone that public corporations in Greece employ too many workers compared to other countries. However, other evidence suggests that many public corporations had been repositories of clientelistic appointments and excessive salaries and pensions. That is, the "fat" and excess might well have been present in public corporations. Therefore, a major distinction is warranted between public corporations and the public sector proper. Any anti-corruption measures as well as wage and pension cuts should have been primarily targeted in the direction of the former. That is actually what has occurred in practice, as the large pensions of some public corporation retirees have been cut the most.

The Greek public sector proper might have its serious problems of internal organization and accountability to its citizens but this is a typical complaint in all high-income countries. The misinformation and generalized demonization of public employees is completely disproportionate and, in the end, self-defeating. Judges, teachers, tax collectors, policemen, firefighters, and a host of other professions are necessary and essential for the economy to function. When you pay judges, policemen, and tax collectors a lot less and you do so in a way that may be perceived as unfair and even illegitimate, you are unlikely to improve their performance and you are very likely to

\footnotetext{
${ }^{5}$ Katsimi and Moutos (2010) provide an overview of Greece's domestic political economy before and after the adoption of the euro.
} 
make the problems of the private use of public office even more serious than they were before the crisis began.

Between 2009 and the end of 2013 total employment in the public sector decreased by more than 236,000 workers or over $26 \%$ of the original number (EU Commission, 2014, Table 7, p.38). That has certainly made Greece's public sector employment closer to the leanest side of European countries and in danger of a commensurate reduction in the quality and quantity of the services provided.

\section{Corruption, military expenditures and public debt}

One major source of corruption in many countries are military procurement contracts, especially for major weapons purchases from abroad. For many years there were rumors about such corruption cases in Greece. Finally, in one case (former Defense Minister Akis Tsochatzopoulos, 1996-2001) was convicted of fraud, partly in connection with the German submarine manufacturer Forestaal.

Greece has considerably higher military expenditures than other Eurozone countries on the order of about $2 \%$ a year. Given that the country is both a member of the EU and NATO, it is surprising that Greece has to spend so much more than its income on military expenditures. What is the impact of these higher expenditures on the country's public debt? Figure 2 shows the actual debt-to-GDP ratio along with a counterfactual one in which Greek military expenditures are equal, as a percent of GDP, to the Eurozone country average. As can be seen, just before the crisis in 2009 the counterfactual ratio was $87 \%$, a ratio that would most likely have been judged sustainable by the international bond markets at the time and the crisis of the Eurozone might have not started in Greece. ${ }^{6}$

Of course, if Greece had such lower military expenditures its governments might have spent more money anyway or, because military expenditures are directly unproductive and especially procurement of military imports have negative multiplier effect (taxes that go abroad), Greece would have even better off than the figure indicates. The point is that a single change towards the Eurozone average in military spending could induce someone to argue that "excess military expenditures explain the Greek debt crisis." I don't think that this is correct as it is incorrect to say that corruption explain the debt crisis.

\section{Enter the euro}

Would Greece have had the experience it has gone through over the past five years without the euro? It would be very hard to argue that a country with its own currency could have experience a more than 25 percent reduction in its income and an unemployment rate of more than 25 percent for more than three year. Certainly that has not occurred in any high-income country since World War II.

\footnotetext{
${ }^{6}$ For the methods and data sources used, please see the explanatory note below the figure. I thank Paul Lowood for finding the data and performing the calculations behind Figure 2 .
} 
Up to the advent of the crisis, the euro allowed cheaper financing than it was previously obtainable by Greek governments and much of it was obtained from abroad instead of, as before, exclusively from domestic sources. This cheaper financing and the borrowing from abroad had the subtle effect of making Greek governments less responsible than they were before the introduction of the euro. Arguably, if we are to judge from the effective dismantling of the elite tax investigation service (SDOE) and other bolder measures in hiring in public corporations, corruption increased and state capacity deteriorated since the introduction of the euro.

Of course, the intention of Mr. Simitis and the other architects of Greece's entry in the eurozone was the opposite. They were hoping that the Greek state would become more responsible and constrained in its fiscal choices, although their own act with the Goldman Sachs swap that helped reduce earlier reported budget deficits gave the strong flavor of what was about to follow.

The introduction of the euro was also hoped to stabilize inflation and reduce the uncertainty associated with exchange rate fluctuations. Instead it brought the disastrous results of the current crisis.

If Greece were the sole country to have run into trouble, one could argue that it was solely Greece's problem and not the euro's. ${ }^{7}$ But one country after another showed signs of trouble under the stress induced by the Great Financial Crisis that had its origins in the US. There were problems lurking in the background that surfaced with the recession that followed the financial crisis. Greece's problem was its fiscal policy and external public debt coupled with diminishing international competitiveness. Ireland, judging from its pre-crisis debt-to-GDP ratio, was the most fiscally responsible country of the eurozone. The culprits there turned out to be private over-indebtedness and its property bubble that led to problems with its banks, followed by the guarantees its government gave to the banks. Portugal had moderate debt-to-GDP ratios but through contagion it was perceived by the bond markets to be the weakest of the rest in terms of size, low growth, and fiscal vulnerabilities. Spain was also nearly as fiscally responsible as Ireland and it also suffered from a property bubble and high private debt. Italy has suffered from high public debt and persistently low growth over the past decade.

Greece was the biggest violator of the Stability and Growth Pact's budget deficit limits and had the highest public debt. The Irish and Spanish crises can be considered largely an outcome of the unclear supervision of, and gaps in responsibilities for, the banks. Portugal has been a victim of the general economic malaise that it has experienced since adopting the euro and the power of the bond "vigilantes," perhaps more so than any of the other countries since there was nothing specifically that was done wrong. But all countries experiencing a crisis have had, since the introduction of the euro, a large expansion of overall indebtedness, whether primarily public or private, that was accompanied by an increase in their current account deficits. Over the same time period, these deficits were matched by an increase in Germany's current account surplus. ${ }^{8}$

\footnotetext{
${ }^{7}$ The next three paragraphs are partly based on Skaperdas (2011a).

${ }^{8}$ See Research on Money and Finance (2010, Fig. 14, 27) and Lapavitsas (2012).
} 
For the eurozone, the problem is not Greek government profligacy or Irish carelessness. If Ireland or Greece were not part of the eurozone, another peripheral country would get into trouble sooner than later. The problem is structural: the weakness of institutions for a monetary union that consists of such diverse and heterogeneous countries that have no independent economic tools other than wage and price adjustments that have been historically known to be crude instruments. ${ }^{9}$ The creators of the euro saw it as primarily a political project, as a back-door way of forcing political integration. Political integration, however, never took off the ground and now we have the rather predictable results.

To recapitulate, without the euro it is difficult to imagine how a crisis of such depth would have occurred. If Greece had retained its own currency, with less borrowing from abroad it would have likely grown less than it did up to 2007 but it would have had the tools - a depreciating exchange rate - to weather the recession much better than it did, without being on the brink of default or surrendering all semblance of national sovereignty. With borrowing more expensive and domestic in its vast majority, its governments would have had better incentives to be more fiscally responsible and would have not eroded its tax and other state capacity as much as they did since the introduction of the euro.

\section{Myth \#4: If only the Greek governments were competent, the targets of the Memoranda in the agreements would not have failed.}

This is the only myth that the previous Greek government did not propagate themselves. It is instead what other domestic and foreign defenders of the troika Memoranda policies want us to believe. The Memoranda targets, however, could not have worked because the effects of the budget cuts were consistently underestimated in the troika's estimates.

For example, in March of 2011 the IMF's estimate for 2011 GDP growth was $-3.0 \%$ and for 2012 the estimate was for a positive 1\% growth (see IMF, 2011, Table 8). The actual outcomes were $-7.1 \%$ for 2011 and $-7.0 \%$ for 2012 . The underestimates have been consistent for subsequent years as well as for other variables such as unemployment.

Since the economy had been contracting much faster than originally estimated by the troika, tax receipts were inevitably lower than estimated and expenditures were higher because of increased spending on items like unemployment insurance. Inevitably, then, the budget deficits became much bigger than originally estimated, precipitating hectoring and calls for additional budget cuts and taxes in order for the government to receive the next tranche of payments from the troika.

\footnotetext{
${ }^{9}$ See Ahamed (2009) for a discussion of the UK's painful and persistent attempt to return to the Gold Standard at pre-World War I exchange rates. A former insider's account (Governor of the Central Bank of Cyprus) shows that, during the crisis, the countries of the eurozone not only did not politically cooperate but grew further apart, playing an increasingly non-cooperative game (Orphanides, 2014).
} 
There was, and still there is, no end in sight for this cycle of cuts, new taxes, further contraction of the economy, greater budget deficits than originally estimated, with more cuts and taxes starting the cycle anew.

The Greek governments could have been highly competent and the objectives would still have failed. They have not been that competent, but they still implemented a large number of measures that were highly unpopular and against stiff opposition. Examples of such measures just for the Papandreou government (up to the end or 2011) included:

- Increased the VAT to $23 \%$, from $19 \%$ or $13 \%$ originally, despite all the calls that it would reduce competitiveness and possibly reduce VAT receipts.

- Eliminated the two "extra" months of pay (Christmas, Easter, and vacation bonuses) and replaced them with fractions of the original pay, before eliminating them altogether.

- Eliminated the raises for seniority in the public sector.

- In addition to the above, it cut a $10 \%$ of salaries of public servants (with reductions that came later totaling more than 30\%).

- Similar, in some cases higher, cuts as the above were implemented on pensions.

- Equalized the pension requirements for men and women.

- Reduced the tax-free income to 5,000 from 12,000 euros.

- Reduced medical expenditure tax deductions to $20 \%$ (from $40 \%$ ) even for income earned in 2010. After 2012, these deductions were effectively eliminated for the vast majority of tax-payers, as a $10 \%$ deduction applies only to expenditures exceeding $5 \%$ of annual income.

- Considerably increased car registration charges from 2010 onwards.

- Implemented a new special "solidarity" tax from ranging from $1 \%$ to $6 \%$ of income.

- Increased bus ticket prices by $20 \%$ and subway ticket prices by $40 \%$.

- Reduced severance pay that private employers pay by up to $50 \%$ (depending on length of notice that is given).

- Introduced new house property taxes.

That is only a sample of the measures implemented by the Papandreou government. The Samaras government that followed the agreement of 2012 implemented additional similar measures. For example, the normal retirement age was raised to 67 (contrary to reporting in some of the European press that it is 65). It is difficult to think of any governments anywhere implementing so many measures within such a short period of time. .

The fiscal adjustment that Greece undertook has been unprecedented, certainly for an OECD country. Primary spending was cut by $35 \%$ relative to the peak (the comparable figures for Ireland, Spain, and Portugal are between 15\% and 18\%) (Maliaropulos, 2015). The primary budget balance increased by $11 \%$ of GDP between 2009 and 2013, whereas taking the effect of recession the "structural" primary budget balance moved by $16 \%$ of GDP between 2009 and 2014 (Maliaropulos, 2015,p.5). Yet the troika and its defenders kept (and its heir, the "institutions," keep) complaining that the governments have "not done enough" or "dragging its feet" and demand more. 
One main concern of the critics has been the slow pace of liberalizing legal and institutional changes by either taking too long to bring bills to parliament or too slow in implementing them once voted into law. In addition to the substantive objections one could bring up against wholesale liberalization, it is surprising that such critics expect from highly unpopular governments to just sneak in such reforms expecting no serious pushback, especially from a society that disagrees with most of them, even among conservative voters. On the contrary, many bills were passed so fast, without adequate legal preparation, that eventually they were declared unconstitutional by the Supreme Court (Council of State) or illegal by lower courts.

The economic effects of the troika's policies were largely predictable and the criticism of the governments of not being zealous enough in pursuing them reveals, at best, a basic unawareness of the limits democratically elected governments have in going against the wishes of their electorates. Still it is difficult to decipher the behavior of the troika and how it served the long-term objective of the survival of the eurozone as it now is or anything close to it. It could have been just a combination of bureaucratic inertia, making an example of presumed "sinners", and letting some well-placed interests making a profit out of Greece's predicament.

\section{Myth \#5: Following the troika's policies would have led Greece back to prosperity.}

In addition to the more immediate budgetary cuts and tax increases, the troika's policies included (i) reductions in wages and prices; (ii) legal and institutional changes aimed at liberalizing labor and other factor markets; and (iii) privatization of public property. I will briefly discuss each of the policies, their ostensible objectives, and possible implications. I will then summarize their likely long-term effects.

\section{Effects of reductions in wages and prices}

The main objective of reducing wages and prices is for the economy to gain international competitiveness. This is the so-called policy of internal devaluation, as opposed to that of external devaluation, whereby a country gains competitiveness through its currency's depreciation which Greece does not have available within the eurozone.

As can already be seen, suppressing wages in such a way is painful, subject to significant resistance, and involves the overturning of much existing labor law. Nevertheless, the substantial reduction in wages did not translate in a reduction in consumer prices until March 2013. Since then the annual consumer price index has been hovering between 1 and 2\% (ELSTAT: www.statistics.gr).

Attempts at internal evaluation are well-known to lead to depression-like conditions with high unemployment that lasts for years. The current experience of Greece within the eurozone is similar to that of the UK after World War I when the pound was brutally brought back to its pre-war Gold-standard equivalence. Yet all the pain, as Keynes had 
warned, was for nothing as the country had to abandon the Gold standard again during the Great Depression (see, e.g., Ahamed, 2009). One major factor that makes internal devaluation very difficult is that, as wages and prices decline, the value of debt does not adjust. That makes debt ever more onerous, leading to both higher reductions in consumption and defaults which in turn lead to credit contraction and further reductions in economic activity and increased unemployment. Then, the cycle repeats itself with no end in sight.

A concrete example might help. Consider a worker with pre-crisis income of 1000 euros a month who had a mortgage of 300 euros a month and other fixed home expenses of 100 euros a months. That would have left 600 euros a month for all other expenses. Now consider a $30 \%-300$ euros -- reduction in monthly income. That would leave 300 euros a month for all other expenses, which is a $50 \%$ reduction in actual consumption and other expenses. That is, the percentage reduction in consumption is likely to be higher than the percentage reduction in wages and such reductions can be expected to have additional deleterious effects on the economy.

Furthermore, some of the workers like the one in our example become unemployed and they are the ones who are likely to stop paying their mortgages and lose their homes, thus inducing a further contraction on credit with additional knock-on effects that can be expected on the economy. ${ }^{10}$ This process of debt deflation is an integral part of internal devaluations that make them fundamentally different from external devaluations, and in the end it seems they never work.

An additional factor that is not usually taken into account in economic analyses but often has its own additional negative economic effects is the increased levels of social conflict. That factor manifests itself in many different ways: increased common crime and organized crime, strikes, other work stoppages, or passive resistance in other different ways. These activities have direct and indirect effects of reducing production but also induce their own dynamic of economic decline. One can identify such effects in parts of central Athens as a result of rampant crime.

\section{Liberalization}

The legal and institutional changes imposed by the troika were meant to both facilitate internal devaluation through the abolition of many existing labor laws and induce structural changes in the economy that would ostensibly contribute to growth. Examples of structural changes that have been pursued include the liberalization of taxis and trucking by effectively abolishing licenses for these professions. Whereas taxi drivers are not the best loved profession in Greece and improvements in their level of service would be welcome, it is hard to see how the contemplated reforms would lead to significantly better levels of service and there is the danger that they would be retrogressive.

\footnotetext{
${ }^{10}$ How unemployment and loss of equity can interact in a complementary fashion during recessions has been theoretically and empirically examined masterfully by Mian and Sufi (2014) using data from the US Great Recession.
} 
As for the wholesale changes in labor law, regardless of the opinion one has about their effectiveness or justice, there is little popular support for them and none of them were part of the program that the current government campaigned on. Thus, it is difficult to reconcile them with a polity that respects the basic democratic rights of its citizens.

What has not been pursued, however, is reform of retail and wholesale markets of basic consumer goods and services, the structure of which is largely oligopolistic. The persistence of inflation up to 2013 might have been related to this problem.

\section{Privatization}

Initially, privatization of public property (ports, airports, public land, some public enterprises) was hoped to bring in 50 million euros and do so within a short few years. Privatizations had brought in 2.6 billion euros until the end 2013 (EU Commission, 2014, p.28) and another 1.5 billion was expected to be received by the end of 2014 . From the beginning of the crisis, the question was who was going to buy public enterprises with high debt and difficult labor relations or public land restrained by riders that would invite legal challenges?

\section{Overall effects}

What have been the effects dictated by the troika and what can we expect if the same policies are imposed on the new government?

There has been a continued decline of incomes, unemployment, with some reduction of prices of domestically produced goods and services. The decline will likely continue for the foreseeable future, especially with the expected demographic decline. The young and anyone who might be able to find employment abroad will leave the country. Thus the most productive segments of the society will stop contributing, reducing taxes further and putting additional pressure on public finances, pensions, and social services.

If the new Greek government were to agree to the conditions offered by the "institutions" (which are essentially no different than those of the troika), any decision of importance to the Greek people will be taken abroad. There will be little semblance of democracy, selfgovernance, and national sovereignty, just as it has occurred over the past five years. This, however, would be the peaceful scenario that ignores the effects of extended government illegitimacy usually brings about: social chaos but also resistance movements.

The former East Germany has lost its young and the most productive inhabitants to the former West Germany and Berlin. Those who have remained behind are mostly the old, the infirm, and those employed by governments. More than twenty years after German reunification, a lady from East Germany claimed that she can distinguish those who come from the East from those who come from the West, especially men: "West Germans are much prouder. They stand straight. East Germans are more likely to slouch. West Germans think East Germans are lazy.” (Lewis, 2011) 
In following the current path, the future of Greece is similar to the present of East Germany, minus the transfers and subsidies from Berlin, minus the right to vote in German elections and all the other benefits of German citizenship, but with the addition of a crushing public debt burden.

\section{Myth \#6: Exit from the eurozone would have been (and still is) the worst possible outcome.}

Having your own currency confers several advantages that had become extremely underappreciated during the boom years of the eurozone.

First, there is little doubt among economists that the easiest mechanism for a country to gain international competitiveness is to have its currency depreciate. With exit from the eurozone, cars and i-phones will become more expensive but food might actually become cheaper. In fact, the introduction of the euro brought distortions in relative prices that economists to this day have trouble understanding, and the introduction a new drachma might help partially reverse these distortions. Regardless of that, though, the benefits of having your own currency as a way of adjusting to international shocks and international competitiveness are well-known and quantitatively important, even though now, given the internal devaluation that has already taken place, they would not be as significant for Greece.

Second, having your own currency implies you tailor monetary policy to the country's immediate needs, instead of having it determined by the needs of the most influential country in a monetary union which are unlikely to be aligned with your own needs. This is especially important in periods or recession and depression like the one currently Greece is in. The country's economy is starved of liquidity. If Greece were to exit the Eurozone, increases in the money supply will be mostly absorbed by increased production and lower unemployment and to a lesser extent by increased prices. Much, of course, would depend on how the (Central) Bank of Greece were to control the money supply and, crucially, whether powerful external actors such as the European Central Bank were to collaborate in controlling the downward overshooting of the exchange that can be expected at the beginning of the transition to a new currency.

Third, the experience of the past five years has amply demonstrated that being in the eurozone is incompatible with democracy in Greece and national sovereignty. ${ }^{11}$ As discussed above (on Myth \#5) following the current path holds more of the same. The

\footnotetext{
${ }^{11}$ As developed by Rodrik (2011) and as applied to the eurozone by O'Rourke (2011), there is a fundamental political "trilemma" between democracy, national determination, and economic globalization. You cannot have all three of them simultaneously. By being part of the eurozone (an instance of economic globalization), you normally give up some national determination, but in the case of Greece even democracy has substantially eroded since all major decisions dictated by the troika are voted against strong popular opposition, and arguably in the case of major votes without the $2 / 3$ majority required by the country's Constitution.
} 
only possibility of remaining within the eurozone and Greeks having any say is to have political unification of all the eurozone countries with full democratic rights for all the citizens of its constituent countries. That would bring some democratic legitimacy in the eurozone, although that would be the end of all national sovereignties. However, not even political unification is likely, let alone political unification with democracy eurozone-wide.

Democratic legitimacy and national determination are not just abstract concepts that are disconnected to people's everyday lives and their work. For the merchant it implies the government's policy towards banks and liquidity in general takes their interests into account. For the worker it implies that their concerns for unemployment and inflation will have to be heard in Athens instead of (not be heard) in Berlin, Frankfurt, or Brussels. The local industrialist will also have a chance to be heard and influence policy.

Thus, economic reasons, democratic legitimacy, national sovereignty, and even basic dignity are all related and point to Greece having its own currency. Most of those who object to exit from the eurozone are mainly concerned with the costs of transition. Won't the foreign debt burden increase even more due to devaluation? How will the banks adjust to the change in currencies? How will the country import essential items like petroleum and pharmaceuticals? What will happen to bank deposits? Won't all this create total chaos?

Those, and many others, are fair questions to ask. What is important is how competent, honest, and ready to defend Greek interests will be those who manage the transition; how fast and flexible will they be in adjusting as unforeseen problems crop up; how able will they be in articulating their actions to the Greek people so that negative reactions are minimized. A completely uncontrolled and unplanned exit from the eurozone will be chaotic and a lot more painful than a controlled and well-planned one.

Others such as Capital Economics (2012) (the winner of the Wolfson prize) have provided detailed guides for the process of exiting the Eurozone and answers to the questions such as those posed above. Because the Greek economy has gone through such a severe trauma over the past five years and public debt is now under English law and mostly owed to official institutions, exit from the Eurozone would have been much easier in 2010 or 2012 that it is now. The main problem now is political, most seriously on how the protracted negotiations for restructuring or forgiving the debt.

In terms of short and medium term, the adjustment of the banking system will take some time with many twists and turns that cannot all be predicted in advance, but the problems should be manageable. As former Czech President Vaclav Klaus mentioned, based on the experience of the breakup of Czechoslovakia and the currency transition there, exiting the eurozone will not involve overwhelming logistical problems (see Capital Economics, 2012, p.24).

Naturally, capital controls will need to be imposed and other measures will have to be taken to ration foreign exchange for the importation of essential items. 
Bank deposits will automatically be adjusted to the new currency as will be all domestic debts. Inevitably, net creditors will lose some and net debtors will gain in the short run but even net creditors might gain in the long run since the economy can be expected to grow faster than if it were to remain within the eurozone.

The transition will be difficult and painful but, if managed properly, the pain will be short term. With its own currency the Bank of Greece and the government will be able to inject much needed liquidity in a currently dying domestic market due to an extreme shortage of credit and liquidity. The increased liquidity along with the beneficial effects of depreciation through import substitution, reduced imports, and possibly increased exports will bring the economy back to life and increase employment. Of course, the government will have to negotiate a narrow path between increased liquidity and keeping inflation within reasonable levels.

A study by UBS (2011 had claimed that Greece's GDP will be cut in half if it were to leave the eurozone. However, the maint assumption of the study was that any devaluation of the new drachma will be immediately matched by increased tariffs from EU countries. The question is who would have an interest in implementing such retaliatory tactics, coordinating them EU-wide, and what would that imply for today's world trading system? To engage in such retaliatory activity, all the EU countries would have to agree, when some of them might also be seriously have to contemplate exit from the eurozone. Why would they want to effectively foreclose such an option to themselves? Moreover, such a retaliatory tariff would have serious implications not just for the future of the EU but for today's globalized world trading system. It would be the beginning of the end of the world as we know it and every country would want to protect itself and its people from the coming tsunami.

That would actually be an additional argument for Greece having its own currency, so as to maintain maximum flexibility in its economic policies, in a much less globalized and possibly poorer world.

In any case, it is highly imperative that the Bank of Greece and the Ministry of Finance have teams secretly working on the scenario of eurozone exit. That could make the difference between a chaotic exit and a well-planned one.

Finally, a default and exit from the eurozone would not have to be done in an overtly adversarial fashion with Germany and other eurozone countries. Once such a move becomes clear or inevitable by circumstances as it might well become, it would be in the interest of all parties to make its effects as smooth as possible. There are many economic and political constituencies within Germany that would find such a possibility welcome and a mutually advantageous move for Greece, Germany, and for the future of a more cohesive and sustainable eurozone. There would be also no reason for Greece to leave the EU or for other countries to demand its expulsion. The apocalyptic scenarios that are circulated are sometimes just part of the negotiating tactics used by one side to prevent 
another side from doing what they want them to do but they do not necessarily have much basis in fact.

\section{Myth \#7: In its negotiations with the troika, the Greek government has had very little bargaining power}

"If you owe the bank a hundred thousand dollars, the bank owns you. If you owe the bank a hundred million dollars, you own the bank." American proverb

Greece owed and owes enough money so that even if it does not "own" its creditors at least it had and has enough bargaining power to negotiate for better terms in paying back its loans and to moderate the troika's austerity demands. Of course, at the beginning of the crisis French and German banks as well as the ECB had the backing of the French and German states and, as we saw, that was decisive in the type of agreement that was reached in 2010. But, then, at the time in addition to bank losses Greece also had the threat of contagion to the bonds of other sovereigns as well as the uncertainty that would have emerged after a Greek default regarding who has obligations on Credit Default Swaps (CDSs). Both the contagion and CDS problems could have frozen the Northern hemisphere's interbank markets. No such threat was invoked or even remotely implied by the Greek governments that were involved in the 2010 and 2012 agreement.

In addition to having a threat that Greece definitely had with default and exit from the eurozone, generally there are two other important conditions that enhance one's bargaining position and make a threat credible. First, you have to believe yourself that your interests differ from those of your adversary, and your adversary knows this. If you personally believe that you will be "rescued" by the bank's representatives out of the goodness of their hearts, even if you owe the bank a hundred million dollars, you are definitely not going to own the bank. The bank will still own you. Second, you need to prepare your side for the ultimate threat you have so that the other side has the reasonable fear that you can carry out the threat. If you don't bring a lawyer and other experts with you when you negotiate with the bank and are not ready to signal a default, you could not expect the bank to take you seriously.

As reviewed above, Greece could have defaulted at any time during the past five years and could have used that as a credible threat in its negotiations with the troika. But the Greek governments apparently fulfilled neither of the two important necessary conditions for successful negotiations.

First, they adopted the framing and perhaps the objectives of the troika and even of the German tabloid Bild about the country and its people. Its visible members appeared unaware of the difference between the objectives of the banks, of the troika, and the people they supposedly were representing. Perhaps they got carried away by the rhetoric about "European solidarity" and "we are all in this together." Such proclamations can be useful but cannot be taken seriously in preparing one's side. Without awareness of the different objectives, no further steps can be taken to create a strong Greek bargaining 
position. Instead of being an independent actor one becomes cognitively captured by the other side.

Without awareness of the differing objectives, the bureaucratic apparatus could not be directed to produce data and arguments that would favor Greek interests. If IMF experts wanted to apply their cookie-cutter approach used in other countries, the Government should have been able to come up with arguments about the harm that particular reforms could induce in Greece. Examples include the harm that some changes in the private labor market would bring about or the supposed 50 billion euros that privatization were to yield.

Preparing for the ultimate threat of default and exit from the eurozone requires the formation of teams of experts beyond the limelight and in secrecy. Such preparation necessitates the development of different scenarios, gaming them and testing the robustness of different approaches. Examples of the myriad issues that have to be considered include how to effectively introduce capital controls in case of exit from the eurozone, to how the bank payment systems need to be converted, to how will liquidity be injected into the economy.

Of course, you need to believe yourself that you are willing to carry out the threat if the other side is willing to take everything to the brink, and subtly communicate to the other side that you have made preparations and you are willing to go to the brink yourself.

There is no evidence or other indirect indications that the key members of Greek governments either believed in negotiating or having made any of the necessary preparation to enhance their negotiating positions vis-à-vis the troika.

It is then completely unsurprising that Finance Ministers was laughed off they tried to "negotiate" with the troika. How could it have been otherwise when they themselves and their governments were not willing to use any threats, let alone believe in them?

Some cautious observers as well as defenders of the Greek governmentss timidity raise the issue of possible national security threats that foreign governments might make if Greece were to take a hard line in bargaining.

Let us note first that very recently countries like Iceland and Hungary have taken very hard lines against the UK's and the Netherlands' wishes (in the case of Iceland) and against the IMF in the case of Hungary. The UK and the Netherlands even made explicit threats if Iceland were not fully to pay back for the losses of the affiliates of Icelandic banks in these two countries. Well, the Icelandic people, contrary to the prescriptions of their terrified political class, voted not to fall for the threats but nothing happened to Iceland. On the contrary, Iceland was preparing for entry into the EU (that was later halted the Icelanders themselves), and nothing bad happened to Hungary either.

The national security threats against Greece would presumably come from Turkey. It is unclear why Germany or another country would have an interest in expending the huge 
diplomatic and other resources to induce another country -- Turkey - to attack Greece if Greece were to default and exit the eurozone. What would it gain from that, especially after an event not to its liking has already taken place? In fact, a recent rather extensive analysis of the security implications of GREXIT does not find any grounds for making any difference (Sambanis and Galariotis, 2015).

\section{On the Strategic Role of Myths and Self-Deceptions}

The preceding discussion shows that the dominant narratives about the Greek debt crisis are problematic even if one were not to have been persuaded that they are totally false.

It is not a priori clear why misconceptions about extremely important policy decisions can persist in democracies with reasonably competitive free presses. This is not the place to fully explain such a phenomenon but a few observations might help in beginning to understand why it occurs.

From an economic viewpoint one can conceptualize what crystallizes as conventional wisdom as an equilibrium that emerges out of a complex interaction between political and economic elites, media owners, news editors, journalists, advertisers and the audience. This is how Hamilton (2006) has analyzed the evolution of the US media markets and found that simplicity of messages and narratives are extremely critical is establishing what is reported as news. Nobody directly controls the message that eventually prevails but interests are certainly important in promoting and propagating narratives that happen to establish themselves in the media more easily and serve the interests of the individual actors who promote them. Once a narrative is established it is difficult to replace it.

Consider the example of Greece. From the beginning of the crisis Greek government officials and most of the press subscribed to the misconceptions, with some of them such as that "default would be catastrophic" (Myth \#1) actively promoted by the then Prime Minister and other government officials. Then, anyone who argued against a particular misconception was likely to face a number of questions that were partly based on other misconceptions, which made the original argument less convincing or more difficult to make. For instance, someone who argued that default would not have been a bad policy could face a series of questions about how Greeks would be ungrateful to our fellow Europeans who have been trying to "rescue" us; how the troika had a good plan that will rid the country of corruption and lead it back to prosperity; how default leads to exit from the eurozone and that, of course, is the worst possible thing that can occur; and so on. That is, the myths that I have argued against work synergistically, complementing one another. Believing one of them tends to make one believe the others. When, then, the dominant narrative in the media is to push most of them, it is difficult for any single person or even organization to argue effectively against them without developing their own comprehensive narrative or counterproposals, and that takes time. 
Furthermore, when a government is under severe pressure externally and internally, it still has the power of the state apparatus in its control. That's also when there is reason to wield that power in ways that it wouldn't wield in normal times. It can influence the mainstream media gatekeepers in subtle and non-subtle ways, who can in turn affect who appears and how those who appear are framed on TV and major newspapers. Those who do appear in the media and would normally be critical have to think harder than normal about what to say and how to say it in ways that will not offend their hosts. Journalists, pundits, and academics can self-sensor or even abstain from expressing views fearing that they will become controversial or offend some of their colleagues.

Moreover, in Greece the main media are owned by oligarchs who had been supporting the policies of the previous governments and, as they were viewing the conditions, they picked on the themes that were both easily digestible to their audience as well as serving their owned perceived interests.

Thus, overall, the myths, misconceptions, and self-deceptions can be created and then reenforced as they serve the interests of those who promote and subsequently, if they continue to do so, propagate them. For the Greek politicians and governments, most of the myths helped justify to the Greek people the policies that were followed. For other Eurozone governments many of the myths helped divert attention from what really happened (e.g., bailing out French and German banks with taxpayer-financed loans to Greece).

However, not everything fits neatly into grant interests because usually political leaders and other actors are seeking mostly short-term advantage. For example, blaming "corrupt" and "lazy" Greeks did increase the ability of the troika to impose harsh terms on the Greek governments in 2010 and 2012 but at the expense of making Greek public debt sustainable. Although there are politicians who might incorporate longer-term incentives in their decision-making, these have not been enough to counteract the shortterm incentives, especially those of others. For example, the President of the European Commission Jean-Claude Juncker by virtue of his position would like to minimize the chance of Greece exiting the Eurozone. Yet, Mr. Juncker does not control the pursestrings and therefore he can only play a coordinating role. Similarly, Chancellor Angela Merkel has an incentive not to be remembered as the Chancellor under whose watch the Eurozone started dissolving, but there are many other German and European political actors who don't have such an incentive.

\section{Self-Deceptions about European Democracy}

Beyond what has become the conventional wisdom about Greece, there is a context of policy-making in the Eurozone and, more widely, in the European Union that has partly fueled the crisis. This context is of much wider significance than what has happened to Greece. Although the problematic context is widely acknowledged with names such as the "democratic deficit," its specific manifestations tend to be subconsciously ignored as 
they create cognitive dissonance to most intellectuals and laymen since they contradict what most consider basic European values. ${ }^{12}$

In terms of policy-making, formally each member country of the European Union has veto power over each decision. What can be more democratic than that? Gradually, however, especially over the past decade de facto decision-making has become very different than what one might originally have expected. A small insiders' circle consisting of European Commission and core country officials makes most important decisions and the rest have very little input, if any, and accept decisions even if they were to harm their own interests and those of the countries they represent.

To obtain the acquiescence of the outsiders, the insiders have both sticks and carrots at their disposable. They can threaten (or, more likely and as effectively, hint of a threat) negative consequences for their country in a policy dimension other than the one under consideration. But even hints of a threat are not usually needed. Simply the hint of social ostracism within the policy group could well do the job. Carrots include the possibility of a future career in the Commission or other European institutions. For a politician in a small or peripheral country a political or even business career beyond their home country can be extremely attractive but requires that such a politician successfully ingratiates himself or herself to key insiders politicians and decision-makers, and obviously does not ruffle any feathers.

Even those at the highest levels - democratically elected prime-ministers - have not escaped the wrath of the insiders as the ousting of Papandreou of Greece and Berlusconi of Italy demonstrates. After this, it is advisable for Europeans to be careful when they accuse others of being insufficiently democratic.

Over time, the insiders tend to "believe their own press" and grow intolerant of different opinions and cling to beliefs that sometimes have an uncertain connection to reality. Many do believe synchronized austerity is the right policy and all is fundamentally fine with the Eurozone, even in the absence of political integration.

Beyond austerity, the way EU economic policies have evolved in favor of deregulation, privatization, reductions in social insurance and the bargaining power of labor they cannot be characterized as anything other than market fundamentalist. The creditorfriendly policies that have been followed and not just in the case of Greece go beyond that as no self-respecting classical liberal would favor such blatant favoritism to an industry.

Until recently, such policy positions could not have been adopted by even conservative, let alone social democratic, parties. Yet we have witnessed a remarkable convergence of traditional conservatives and social democrats/socialists towards that policy mix. Because

12 This problem is analytically distinct both from the aforementioned Rodrik's (2011) trilemma due to membership in the Eurozone and from the general erosion of democracy due to globalization that Crouch (2008) has called "post-democracy." 
of the gradual adoption of unpopular as well as disastrous policies, for many countries this is leading to the political destruction of the traditional center. The recent successes of the Front National could better be attributed to the fact that its economic program is to the left of the practices of the Socialist Party and less to a greater affinity of the French electorate for fascism.

Instead of attributing the problems to the policies adopted and the increasingly authoritarian nature of intra-European politics there is a tendency on the part of many intellectuals and opinion-makers of either denial of the problems or accusing the messengers of being "bad" Europeans or wanting to harm Europe. Circling the wagons around "Europe", instead of confronting reality and working to provide viable long-term solutions do not just concern the Greek debt crisis. If Greece did not exist, then the next weak link in the eurozone would become the problem of the day. The problems of democratic legitimacy of the Eurozone and of the EU more generally need to be confronted instead of denied.

\section{Concluding Remarks}

Part of the argument I have advanced in this paper, can be well-summarized by the following Woflgang Streeck quote:

International solidarity, which in practice amounts to a punitive austerity policy ordered from abroad and above, holds the citizens of an insolvent debt state jointy liable for their past governments. The justification is supposed to be that they democratically elected them. Democracy thus serves to construct an identity between citizens and government, between the electoral as principal and the government as agent, which is sufficiently deep to require that citizens repay out their own pockets the loans contracted in their name - regardless of whom they voted for and whether any of the borrowed money ever found its way to them. Moreover, as state citizens they are denied what be readily available to them as economic citizens: something like a bankruptcy seizure exemption threshold, as might be safeguarded by the European Convention on Human Rights. (Streeck, 2014, p.95)

In early June 2015 (when these lines are written) as Greek residents confront an unsustainable debt, its new government continues to be locked in protracted negotiations with the so-called "institutions" (the renamed troika). After more than four months of negotiations and ever-decreasing liquidity for the Greek banking system and economy, there appear to be only two options. The first option is essentially complete capitulation on the part of the new government without a prospect for debt relief. That is what Mr. Jean-Claude Juncker presented Mr. Tripras on June $3 .{ }^{13}$ The second option is default,

\footnotetext{
13 The terms were worse than those offered the previous government that lost the election could not fulfill. The term have been worse primarily because, without any debt relief and the worse-than-expected performance of the Greek economy (that always happens), additional taxes and spending cuts will have to be found to stay within the parameters of the agreement of 2012. The new Greek government's proposal has not been that far in terms of primary surplus required but did not cross some additional "red" lines on
} 
first on principal payments to the IMF at the end of June, followed by larger payments to the ECB in July and August. Under the second option it would be difficult for Greece to eventually avoid exit from the Eurozone (but would have to do so with essentially no preparation).

Reducing the debt so as to make it sustainable without continual cuts in spending and tax increases would be the obvious middle ground, but it does not appear in the cards, at least for now. Thus far, the strategy that has been followed towards Greece is analogous to the Versailles agreement strategy that was followed after World War I towards Germany. The winners of the Second World War learned from the disastrous effects of such a punitive approach to debt and reparations and followed the very different strategy of the Marshall Plan and the debt forgiveness conference of 1953. Something analogous is needed for Greece but the propagation of, and wide belief in, the myths that I have reviewed are a serious impediment in this case.

The IMF recognizes that debt relief is necessary for a new program and its initial acquiescence to the 2010 agreement without creditor write-offs has been fateful (see IMF, 2010, and Blustein, 2015) but the rest of the troika cannot go along. The Spanish, German, or Finnish governments would have a hard time justifying to their own people another "rescue" for the "corrupt" and "lazy" Greeks. Moreover, any concession to a new Greek government that has left-wing origins would encourage electoral challenges from the left in other countries. Finally, debt relief would imply an admission that the previous agreements were faulty and a challenge to the decision-making apparatus of the Eurozone.

If the new Greek government capitulates to an "extend-and-pretend" agreement without substantial debt relief, the moment of crisis will be postponed but with continued deterioration of the Greek economy, society, and politics. If there is default and exit from the eurozone, there is the danger of a reactivation and intensification of the worst myths and the demonization of Greece and its government.

privatization, layoffs, and further reduction in pensions and implied some debt relief. For a comparison of the proposals, see Munchau (2015). 


\section{REFERENCES}

Ahamed, Liaquat (2009), Lords of Finance: The Bankers Who Broke the World, Penguin Press, New York.

Blustein, Paul (2015), "Laid Low: The IMF, The Euro Zone and the First Rescue of Greece," CIGI paper no. 61, April.

Capital Economics (2012), "Leaving the Euro: A Practical Guide," (lead author: Roger Bootle), revised resubmission for the Wolfson Prize, June 4.

Crouch, Colin (2008), Post-Democracy, Polity Press, Cambridge, UK.

EU Commission (2014), “Second Economic Adjustment Fourth Review”, April.

http://ec.europa.eu/economy finance/publications/occasional paper/2014/op192 en .htm

Feldstein, Martin (2011) "Vaclav Klaus and the Euro," March, NBER. http://www.nber.org/feldstein/essaysinhonorofVaclavKlaus.pdf

Graeber, David (2012), Debt: The First 5,000 Years, Melville House, New York.

Hamilton, James T. (2006), All the News that's Fit to Sell: How the Market Transforms Information into News, Princeton University Press, Princeton.

International Monetary Fund (IMF) (2010), Office Memorandum (strictly confidential) Subject: Board Meeting on Greece's request for an SBA, May 10, 2010.

http://online.wsj.com/public/resources/documents/Greece-IMF-2010-Bailout-Minutes.pdf

International Monetary Fund (IMF) (2011), Greece: Third Review Under the Stand-By Arrangement, Country Report No. 11/68, March.

Katsimi, Margarita and Moutos, Thomas (2010), "EMU and the Greek Crisis," European Journal of Political Economy, December, 26(4), 568-576.

Lapavitsas, Costas (2012), Crisis in the Eurozone, Verso, London.

Lewis, Michael (2011), “It's the Economy, Dummkopf!," Vanity Fair, September. http://www.vanityfair.com/business/features/2011/09/europe-201109

Malliaropulos, Dimitris (2015), "Greek Economy: Current State, Challenges and Prospects," March 23 presentation, Bank of Greece.

https://www.eventosbbva.com/BBVA/media/uploaded/EVBBVA/event 329/23 DM2 OGreek:20economy20march2023202015.pdf

Mian, Atif and Sufi, Amir (2014), House of Debt, The University of Chicago Press, Chicago. 
Munchau, Wolfgang (2015), “Two Dismal Economic Plans for Greece,” Financial Times, June 8.

http://www.ft.com/intl/cms/s/0/eb7170b4-0b6d-11e5-994d-

00144feabdc0.html\#axzz3cUJVLxcr

OECD (2011), Government at a Glance, OECD Publishing.

http://www.oecd-ilibrary.org/governance/government-at-a-glance-2011_gov_glance-

$\underline{\text { 2011-en }}$

O’Rourke, Kevin H. (2011), “A Tale of Two Trilemmas,” Trinity College Dublin, March.

Orphanides, Athanasios (2014), "The Euro Area Crisis: Politics over Economics," Atlantic Economic Journal, 42(3), 243-263.

Research on Money and Finance (2010), "Eurozone_Crisis: Begar Thyself and ThyNeighbour," C.Lapavitsas, A. Kaltenbrunner, D. Lindo, J. Michell, J.P.Painceira, E. Pires, J. Powell, A. Stenfors, N. Teles, Occasional Report 1, March.

www.researchonmoneyandfinance.org

Rodrik, Dani (2011), The Globalization Paradox: Democracy and the Future of the World Economy, W.W.Norton, New York.

Sambanis, Nicholas and Galariotis, (2015), "Is GREXIT a Threat to Greece's Security," Washington Post, Monkey Cage Blog, May 3.

http://www.washingtonpost.com/blogs/monkey-cage/wp/2015/05/03/is-grexit-a-threat-togreeces-security/

Skaperdas, Stergios, (2011a)"Policymaking in the Eurozone and the Core vs. Periphery Problem," CESifo Forum, 2/2011, 12-18 - downloadable in:

http://www.cesifogroup.de/portal/page/portal/ifoHome/bpubl/b2journal/30publforum/_publforum?item_lin k=forumindex $2-11 . h t m$

Skaperdas, Stergios, (2011b), "Seven Myths about the Greek Debt Crisis," University of California, Irvine working paper, October.

Streeck, Wolfgang, (2014), Buying Time: The Delayed Crisis of Democratic Capitalism, Verso, London.

UBS, (2011), "Euro_break-up - the consequences,” UBS Investment Research, Global Economic Perspectives, September. 


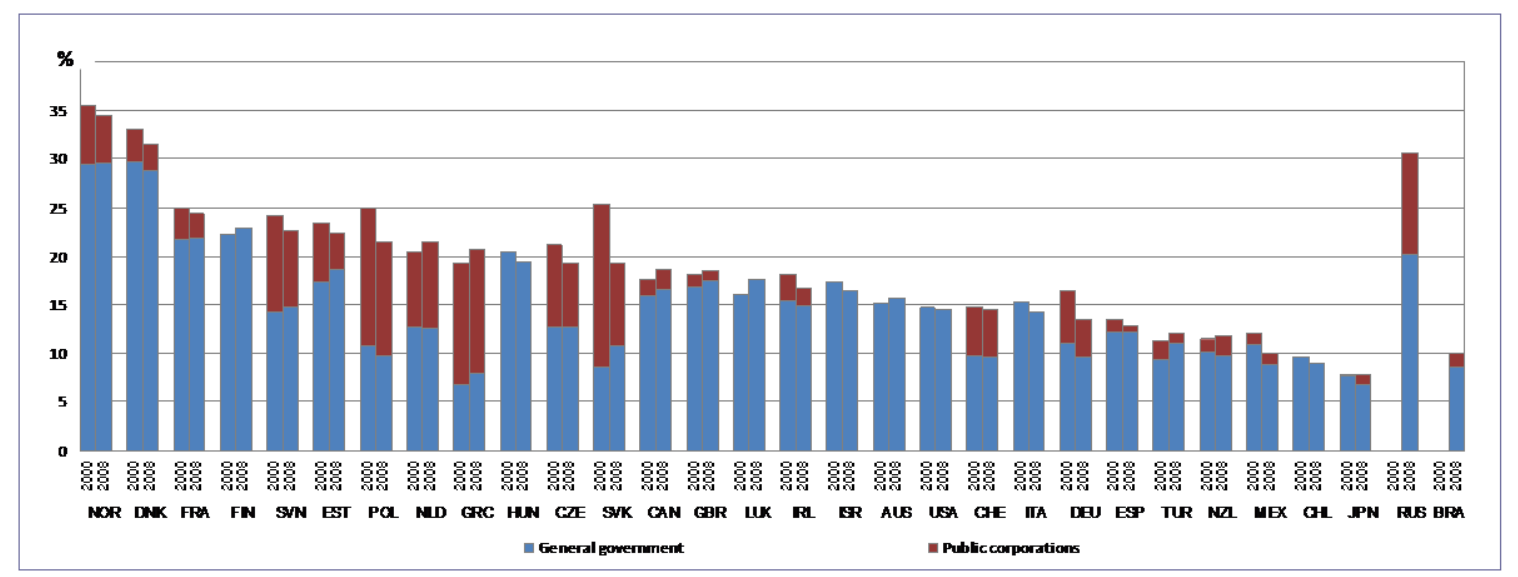

Figure 1: Employment in general government and public corporations as a percentage of the labour force (2000 and 2008). Red bars represent employment in public corporations.

This is Figure 21.2 in OECD (2011).

Source: International Labour Organization (ILO), LABORSTA database. Data for Turkey are from the Ministry of Finance and the Turkish Statistical Institute. Data for Japan for employment are from the Establishment and Enterprise Census. Data for Korea were provided by government officials.

Japan: Employment is not classified according to SNA definition and are substituted by direct employment by central or sub-central governments.

Data for Iceland are missing.

Data for 2000 for Korea are missing and this country is not included in the average (OECD32).

Data for Australia, Chile and United States refer to the public sector (general government and public corporations) Data for Austria, Czech Republic, Italy, Netherlands New Zealand and Poland are expressed in full-time equivalents (FTEs). In New Zealand FTEs are included for education, health and community services and personal and other services.

Finland, Israel, Mexico, Poland and Sweden: 2007 instead of 2008.

France, Japan, New Zealand and Portugal: 2006 instead of 2008.

Russian Federation; 2005 instead of 2008; Brazil and South Africa 2003 instead of 2008. 


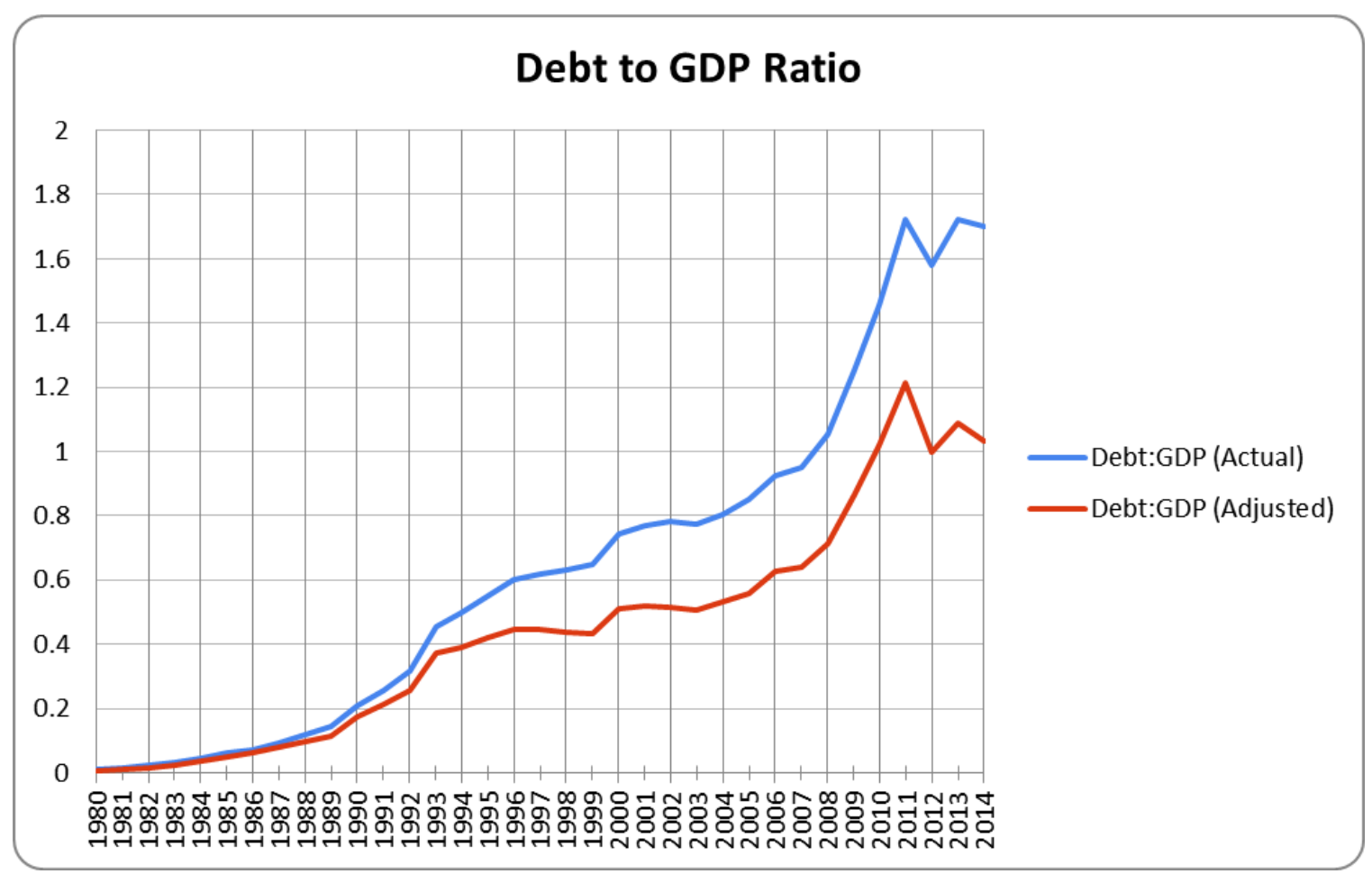

Figure 2: Debt-to-GDP ratios, with and without excess military expenditures

Calculated from the following data sources: SIPRI Military Expenditures, IMF World Economic Outlook, Bank of Greece for interest rates.

Calculation method: Excess military expenditures were calculated as the difference between actual military expenditures and the average of Eurozone military expenditures from 1988 onward; for 1980-1987, average Eurozone military expenditures were approximated with the NATO European average. For each year the accumulated excess military expenditures were calculated using average bond and loan interest rates provided by the Bank of Greece and were subtracted from actual debt to arrive at the adjusted counterfactual debt. 